US Army Corps

of Engineers ${ }_{\circledast}$

Engineer Research and

Development Center

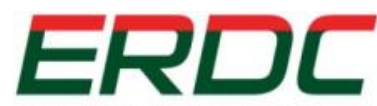

INNOVATIVE SOLUTIONS for a safer, better world

\title{
Passive Gamma-Ray Emission for Underwater Sediment-Disturbance Detection
}

Jay L. Clausen

July 2017

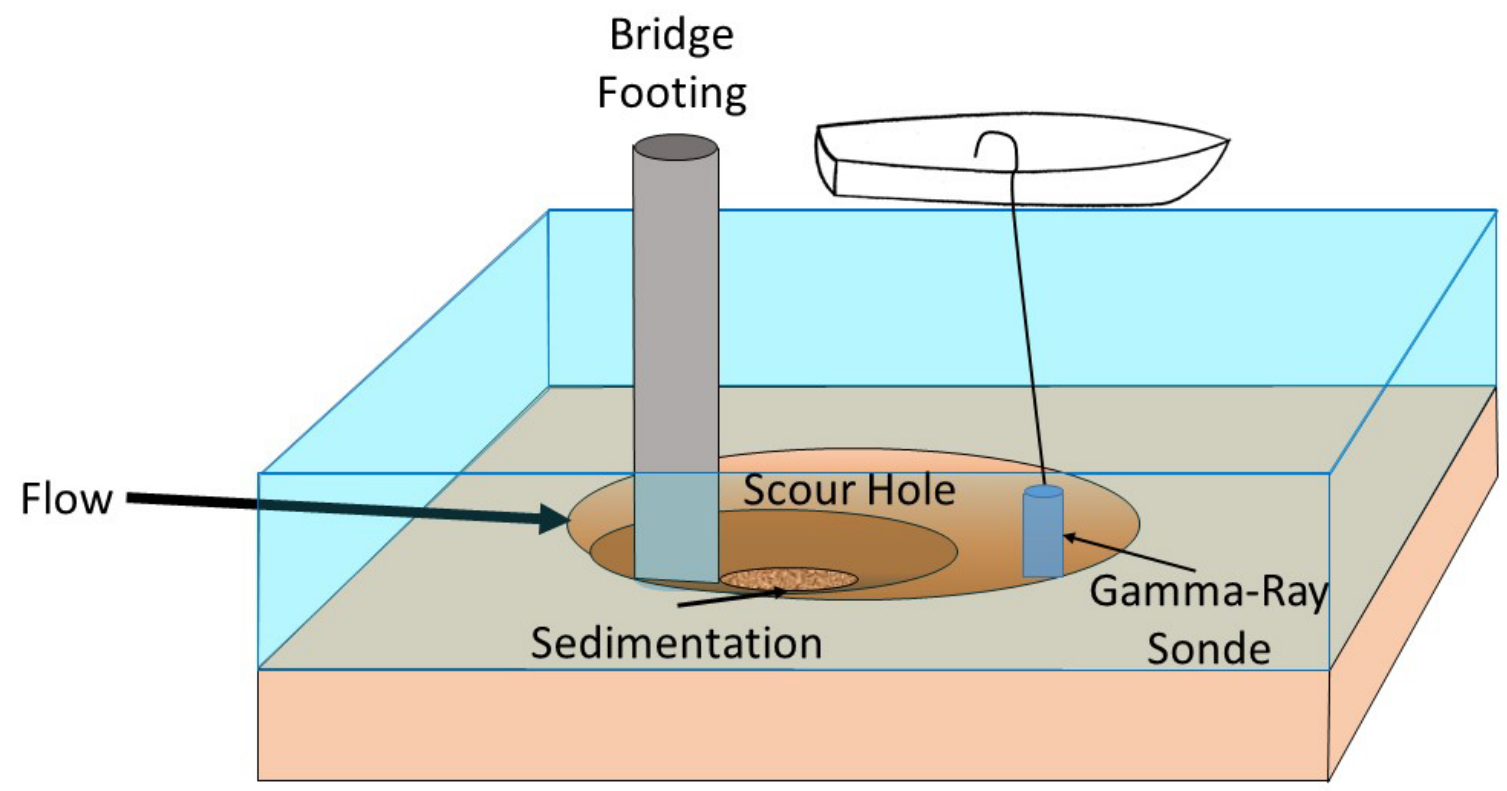


The U.S. Army Engineer Research and Development Center (ERDC) solves the nation's toughest engineering and environmental challenges. ERDC develops innovative solutions in civil and military engineering, geospatial sciences, water resources, and environmental sciences for the Army, the Department of Defense, civilian agencies, and our nation's public good. Find out more at www.erdc.usace.army.mil.

To search for other technical reports published by ERDC, visit the ERDC online library at http://acwc.sdp.sirsi.net/client/default. 


\section{Passive Gamma-Ray Emission for Underwater Sediment-Disturbance Detection}

Jay L. Clausen

U.S. Army Engineer Research and Development Center (ERDC)

Cold Regions Research and Engineering Laboratory (CRREL)

72 Lyme Road

Hanover, NH 03755-1290

Final Report

Approved for public release; distribution is unlimited.

Prepared for Office of the Technical Director

U.S. Army Engineer Research and Development Center (ERDC)

Cold Regions Research and Engineering Laboratory (CRREL)

72 Lyme Road

Hanover, NH 03755-1290 


\section{Abstract}

Sediment erosion around physical structures in surface water (e.g., bridge footings) is an important phenomenon to monitor. Traditional assessment methods rely on divers to make physical observations and measurements. Often, high currents and the high degree of turbidity of the water make these observations difficult. High turbidity can also prevent lowering a camera from a boat to make indirect visual observations.

Another possible approach to this problem is the use of gamma-ray spectrometry. This study used a handheld sodium iodide gamma-ray detector to collect in situ gamma-ray spectra of two soils submerged in water. Study results indicate that naturally occurring gamma rays being emitted by the sediment are detectable underwater. Further, the difference in gamma-ray intensity reflects density differences in the sediment due to disturbances such as erosion. A difference between the Potassium 40 (40K) activity of uncompacted and compacted soil and a comparable rate of $40 \mathrm{~K}$ signal attenuation as standing water depth increased suggests that underwater detection of in situ $40 \mathrm{~K}$ gamma-ray emissions is a potentially viable approach to assessing underwater sediment erosion.

DISCLAIMER: The contents of this report are not to be used for advertising, publication, or promotional purposes. Citation of trade names does not constitute an official endorsement or approval of the use of such commercial products. All product names and trademarks cited are the property of their respective owners. The findings of this report are not to be construed as an official Department of the Army position unless so designated by other authorized documents. 


\section{Contents}

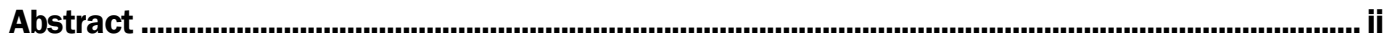

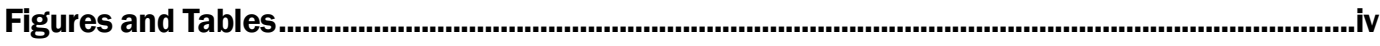

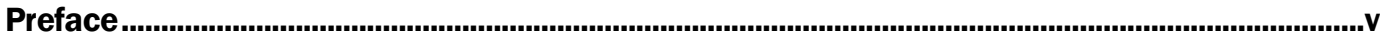

Acronyms and Abbreviations .............................................................................................................vi

Unit Conversion Factors .......................................................................................................................vii

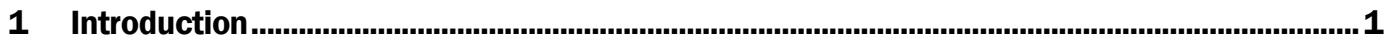

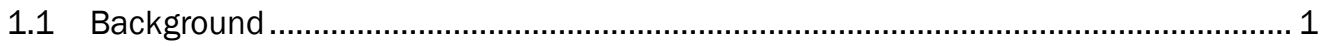

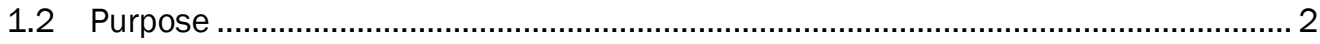

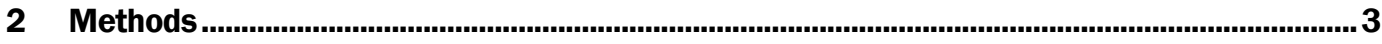

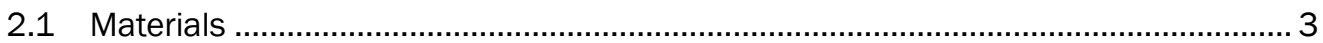

2.2 Proctor density measurements ..................................................................... 3

2.3 Gamma-ray spectrometer soil measurements................................................. 4

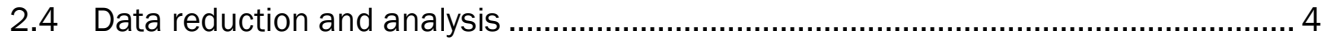

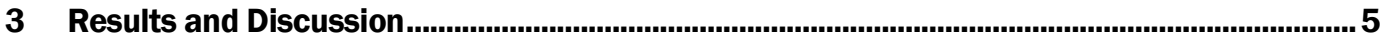

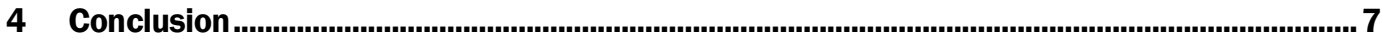

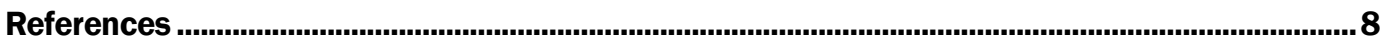

Report Documentation Page 


\section{Figures and Tables}

\section{Figures}

1 A Proctor mold within the lead-shield box .......................................................................

$240 \mathrm{~K}$ activity $(\mathrm{pCi} / \mathrm{g})$ versus submersion depth $(\mathrm{cm})$ for sand compacted at 12 (SD12) and 26 (SD26) blows per lift and uncompact silty loam (SLO). The dotted line signifies soil with too few data points to complete a regression analysis ........................ 6

\section{Tables}

1 Selected physical and chemical properties of the soil material used in this study ${ }^{1}$ reported as percents.. 


\section{Preface}

This study was conducted for the Office of the Technical Director, U.S.

Army Engineer Research and Development Center, Cold Regions Research and Engineering Laboratory (ERDC-CRREL).

The work was performed by the Biogeochemical Sciences Branch (CEERD$\mathrm{RRN}$ ) of the Research and Engineering Division (CEERD-RR), ERDCCRREL. At the time of publication, Dr. Justin Berman was Chief, CEERDRRN, and CDR J. D. Horne, USN (Ret), was Chief, CEERD-RR. The Deputy Director of ERDC-CRREL was Dr. Lance Hansen, and the Director was Dr. J oseph L. Corriveau.

COL Bryan S. Green was Commander of ERDC, and Dr. David W. Pittman was the Director. 


\section{Acronyms and Abbreviations}

$\begin{array}{ll}\mathrm{Al}_{2} \mathrm{O}_{3} & \text { Aluminum Oxide } \\ \text { ANOVA } & \text { Analysis of Variance } \\ \mathrm{CRREL} & \text { Cold Regions Research and Engineering Laboratory } \\ \mathrm{ERDC} & \text { U.S. Army Engineer Research and Development Center } \\ \mathrm{Fe}_{2} \mathrm{O}_{3} & \text { Iron Oxide } \\ 40 \mathrm{~K} & \text { Potassium } 40 \\ \mathrm{ICP}_{\mathrm{MS}} & \text { Inductively Coupled Plasma-Mass Spectrometry } \\ \mathrm{K} & \text { Potassium } \\ \mathrm{SiO}_{2} & \text { Silicon Dioxide } \\ \mathrm{USEPA} & \text { U.S. Environmental Protection Agency }\end{array}$




\section{Unit Conversion Factors}

\begin{tabular}{|l|l|l|}
\hline Multiply & By & To Obtain \\
\hline cubic feet & 0.02831685 & cubic meters \\
\hline degrees Fahrenheit & $(\mathrm{F}-32) / 1.8$ & degrees Celsius \\
\hline foot-pounds force & 1.355818 & joules \\
\hline inches & 0.0254 & meters \\
\hline inch-pounds (force) & 0.1129848 & newton meters \\
\hline pounds (force) & 4.448222 & newtons \\
\hline pounds (force) per foot & 14.59390 & newtons per meter \\
\hline pounds (mass) & 0.45359237 & kilograms \\
\hline
\end{tabular}




\section{Introduction}

\subsection{Background}

Previous studies at the U.S. Army Cold Regions Research and Engineering Laboratory (CRREL) demonstrated the effectiveness of using gamma-ray spectrometry for detecting terrestrial soil disturbance (Clausen et al. 2016). There is interest in potentially applying this approach to detecting sediment disturbance, such as erosion underwater. Clausen et al. (2016) provides background on gamma-emission behavior and the approach to exploiting this phenomenology for assessing soil disturbances. The present limited-scope study tested the applicability of gamma-ray detection underwater as a means for evaluating sediment erosion.

Sediment erosion around the base of a bridge pier, bridge scour, is the leading cause of bridge collapse in the United States (Briaud et al. 2005). To mitigate this issue, bridge foundations must be routinely inspected and monitored. Traditional inspection techniques use divers and basic instrumentation to measure the depth of scouring. The disadvantage of this technique is that maximum scour depth may be inaccurate if the scour hole has been refilled in with loose sediment. In the past decade, there have been many techniques developed to enhance the accuracy of monitoring scour depth. These can be divided into three categories: single use, long-term monitoring, and surveying devices. Single-use devices are installed vertically in the riverbed; when scouring exceeds burial depth, they float out, which sends a signal to the monitoring personnel. The disadvantage of this technique is that the devices need routine maintenance; and once they float out, they need to be replaced (Prendergast and Gavin 2014). Long-term monitoring devices, such as Fiber-Bragg grating, magnetic sliding collars, and driven rod systems, have the advantage of continuous scour monitoring over time. However, they are expensive to install, and they may be biased by bridge vibration and water hydraulics (Prendergast and Gavin 2014). Surveying with ground-penetrating radar to create an accurate depiction of the structure at depth and a subterranean model of the underwater lithology can be used to assess the scour depth around bridge footing (Anderson et al. 2007). The disadvantage is that it reflects only the scouring at a given time; and without additional references or markers, it is difficult to measure the rate of scour over time. 
Clausen et al. (2016) found that as sediment compaction rate increased, Potassium 40 (40K) activity decreased, and they suggested the use of gamma-ray detection of $40 \mathrm{~K}$ activity as a means of tracking land-use disturbance, such as excavation.

\subsection{Purpose}

Following the same principle, the present limited-scope study explores the use of this technique to assess the extent of underwater erosion around bridge piers. Bridge monitoring programs could use this technique in establishing sediment densities around the base of the pier then measuring in a radial transect determine where eroded or filled-in sediment meets the original foundation. In a lab setting, this study assessed the influence of sediment-surface submersion depth on $40 \mathrm{~K}$ activity for a sandy soil at two compaction rates and for an uncompacted silt loam soil by using a handheld sodium iodide gamma-ray detector to collect in situ gamma-ray spectra. 


\section{Methods}

\subsection{Materials}

This study used sand and silty loam soil types with distinct elemental composition and potassium content (Table 1). Soil names are merely contrived names based on the sampling location or storage area from which the soil material was obtained. The Cemetery and EGP soils hereafter are referred to as SD and SL, respectively, followed with a number. The number reflects the blow count for compaction of the soil. A zero value indicates noncompacted soil. All the soil materials used are from soil samples taken in the field. The goal was to obtain soils that represent distinct textures and potassium content.

Soil particle size distribution (i.e., soil texture) was determined via the hydrometer method, ASTM D422-63 (ASTM 2007). The metal content of the soils was determined by acid digestion and inductively coupled plasma-mass spectrometry (ICP-MS) using U.S. Environmental Protection Agency (USEPA) method 3050B (USEPA 2016). Clausen et al. (2016) contains additional analytical data on the soils.

Table 1. Selected physical and chemical properties of the soil material used in this study ${ }^{1}$ reported as percents.

\begin{tabular}{|l|l|l|l|l|l|l|l|l|}
\hline $\begin{array}{c}\text { Soil Name } \\
\text { (Designation) }\end{array}$ & \multicolumn{1}{|c|}{ Sand } & \multicolumn{1}{|c|}{ Silt } & \multicolumn{1}{|c|}{ Clay } & Soil Type & $\mathrm{Fe}_{\mathbf{2}} \mathrm{O}_{\mathbf{3}}$ & $\mathrm{Al}_{\mathbf{2}} \mathrm{O}_{\mathbf{3}}$ & \multicolumn{1}{|c|}{$\mathrm{SiO}_{2}$} & \multicolumn{1}{c|}{$\mathrm{K}$} \\
\hline Cemetery (SD) & 94.5 & 5.5 & 0 & Sand & 2.1 & 14.4 & 54.2 & 3.55 \\
\hline EGP (SL) & 20.3 & 63.2 & 16.5 & Silt Loam & 6.5 & 14.2 & 61.3 & 2.8 \\
\hline
\end{tabular}

$\mathrm{Fe}_{2} \mathrm{O}_{3}=$ iron oxide; $\mathrm{Al}_{2} \mathrm{O}_{3}=$ aluminum oxide; $\mathrm{SiO}_{2}=$ silicon dioxide; $\mathrm{K}=$ potassium

${ }^{1}$ Soil particle size analysis reported on a percentage of the fine-earth (i.e., $<2 \mathrm{~mm}$ ) basis. All elemental analysis results reported on an oven-dry $\left(105^{\circ} \mathrm{C}\left[220^{\circ} \mathrm{F}\right]\right)$ basis.

\subsection{Proctor density measurements}

For each sand-soil treatment, desired densities were prepared by placing 5 lifts (i.e., layers) of soil, approximately $900 \mathrm{~g}$ (1.98 lb) of material, into steel $152.4 \mathrm{~mm}$ (6 in.) diameter Proctor molds. The Proctor mold was then placed into a Durham Geo Enterprises S-335 Compactor. Each lift of soil was pneumatically hammered to the desired blow count by using a $44.48 \mathrm{~N}$ (10 lb) rammer dropped from a height $457.2 \mathrm{~mm}$ (18 in.), producing a compactive force of $2700 \mathrm{kN}-\mathrm{m} / \mathrm{mm}^{3}\left(56,000 \mathrm{ft}-\mathrm{lb} / \mathrm{ft}^{3}\right)$, following method ASTM D1557-12 (ASTM 2012). The influence of compaction on $40 \mathrm{~K}$ detection was measured using sand compacted at 12 and 26 blows per 
lift (referred to as SD12 and SD26). The silty loam was not compacted (referred to as SL0). The total mass of soil in each Proctor mold was approximately $4500 \mathrm{~g}(9.92 \mathrm{lb})$.

\subsection{Gamma-ray spectrometer soil measurements}

After preparation of a soil sample in the Proctor mold, the mold was filled to a desired submersion depth with tap water and left to settle for over $1 \mathrm{hr}$. The mold was placed into the center of a lead-lined enclosure (Figure 1), and the gamma spectrometer was positioned and centered at a distance $5 \mathrm{~cm}$ ( 2 in.) above the surface of the standing water.

Figure 1. A Proctor mold within the lead-shield box.

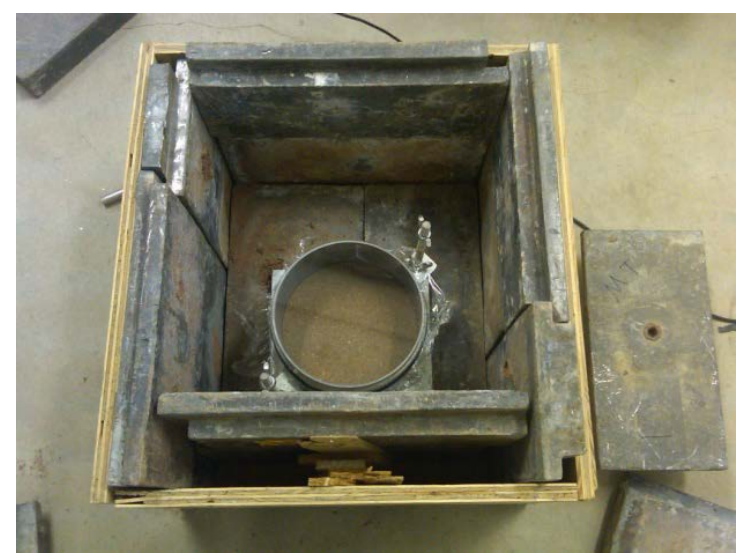

Analysis consisted of using a Canberra Osprey 2x2 NaI Gamma Spectrometer and Gamma Acquisition and Analysis software. The acquisition interval was $4 \mathrm{hr}$ and generally followed the procedures outlined in ASTM C1402 (ASTM 2009). Check sources were tested daily in accordance with the methodology outlined in Clausen et al. (2016).

\subsection{Data reduction and analysis}

Raw data consisted of spectra for each soil treatment and submersion depth, from which intensity (detector counts) and area of the $40 \mathrm{~K}$ gammaray peak was extracted and $40 \mathrm{~K}$ activity calculated using the instrument software. A linear regression using the analysis of variance (ANOVA) approach in the statistical program R package "stats" (version 2.15.3) was used to determine trends in attenuation of $40 \mathrm{~K}$ activity for each compaction rate and soil type at various submersion depths. 


\section{Results and Discussion}

The primary objective of the study was to determine if there is a measurable relationship between soil $40 \mathrm{~K}$ activity and soil submersion depths for a sand and a silty loam at various compaction rates. For each of the soil treatments, this study observed an attenuation in the $40 \mathrm{~K}$ signature as the height of standing water increased, indicating that soil submersion plays an important role in $40 \mathrm{~K}$ signature detection when using passive gamma rays.

Figure 2 shows that $40 \mathrm{~K}$ activity was a direct function of submersion depth for compacted sands and uncompact silty loam. This inverse regression relationship was statistically significant for uncompact silt loam $(\alpha=0.05)$. A decline in $40 \mathrm{~K}$ activity as a function of standing water depth was observed for sand compacted at 12 and 26 blows per lift. Although this trend is congruent with the silty loam, there was not a statistically significant relationship between 40K and depth for SD12 and SD26, attributable to insufficient submersion depths ( $\alpha=0.05$ ). SD12 was measured at only 0 and $2 \mathrm{~cm}$ ( 0 and $0.8 \mathrm{in}$ ), which is insufficient for determining a regression relationship. SD26 was measured at 0,2 , and $4 \mathrm{~cm}(0,0.8$, and $1.6 \mathrm{in}$.) of standing water and may require additional depth measurements to determine if there is a significant regression relationship for this soil treatment. These linear models project that $40 \mathrm{~K}$ activity will no longer be detected at $18.3 \mathrm{~cm}$ (7.2 in.) for SD26 and $7.2 \mathrm{~cm}$ (2.8 in.) for SL0 (Figure 2).

$$
\begin{aligned}
& \text { SD26 40K activity }=68872-3762.5 \times \text { Depth }(\mathrm{cm}), R^{2}=0.84 \\
& \text { SL0 40K activity }=26374.37-3680.18 \times \text { Depth }(\mathrm{cm}), R^{2}=0.85
\end{aligned}
$$

The slopes for the SD26 and SL0 linear regressions were not significantly different. However, the y-intercepts for SD26 and SL0 were significantly different $(\alpha=0.05)$. This indicates that SD26 had significantly more $40 \mathrm{~K}$ activity than SL0 (Figure 2). SL26 contained a greater amount of potassium than SL0, which is positively correlated with $40 \mathrm{~K}$ activity (Clausen et al. 2016) and may explain this discrepancy. Because the slopes were nearly identical for the sand and silt loam, it is likely that a model for $40 \mathrm{~K}$ activity at various sediment compaction rates could be developed that is applicable across multiple soil types. Do note that this study used two different soil types for this analysis, and future research should investigate $40 \mathrm{~K}$ activity as a function of compaction rates within the same soil type. 
Figure 2. $40 \mathrm{~K}$ activity $(\mathrm{pCi} / \mathrm{g})$ versus submersion depth $(\mathrm{cm})$ for sand compacted at 12 (SD12) and 26 (SD26) blows per lift and uncompact silty loam (SLO). The dotted line signifies soil with too few data points to complete a regression analysis.

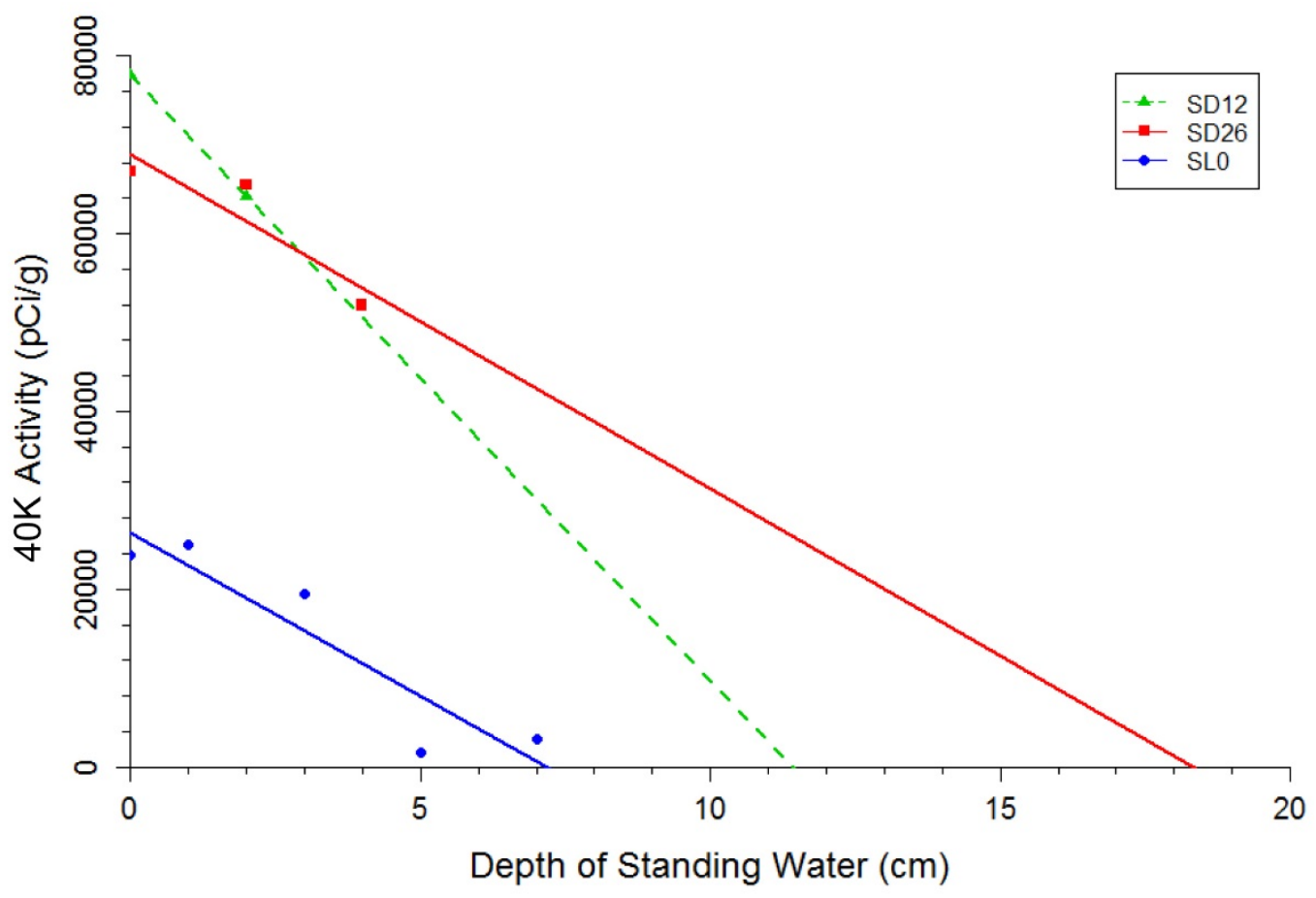

Initial results show that SD12 had greater 40K activity compared to SD26. Clausen et al. (2016) found the same attenuation in $40 \mathrm{~K}$ activity when compaction rate increased for a given soil type. However, developing a definitive relationship between submersion depth and 40K activity for various compaction rates requires more data.

Soil minerology and soil-forming processes control the abundance of $40 \mathrm{~K}$ available in the soil. However, the $40 \mathrm{~K}$ gamma-emission signature is attenuated by scattering that occurs as $40 \mathrm{~K}$ passes through water trapped in soil pores (Clausen et al. 2016). Therefore, the hypothesis was that as a $40 \mathrm{~K}$ gamma ray passes through standing water above the soil surface layer, the same signature attenuation through particle scattering would occur, decreasing the $40 \mathrm{~K}$ activity as water depth increased. The study found that as submersion depth increased, $40 \mathrm{~K}$ activity decreased at comparable rates for both soil types. 


\section{Conclusion}

This study established at lab scale the relationship between underwater soil depth and gamma emissions from the soil surface to detect $40 \mathrm{~K}$ activity. It tested multiple depths and found that as soil submersion depth increased, the detection of $40 \mathrm{~K}$ activity decreased. Although $40 \mathrm{~K}$ activity was significantly different for the sand and silty loam soil type, the relationship between submersion depth and $40 \mathrm{~K}$ signal attenuate was comparable. Further investigation into $40 \mathrm{~K}$ activity at various compaction rates within a soil type may lead to the development of a model to assess underwater soil density and how it relates to bridge scouring. The present work shows promise and potential for the use of gamma-ray spectroscopy for underwater soil disturbance and erosion monitoring. 


\section{References}

Anderson, N. L., A. Ismael, and T. Thitimakorn. 2007. Ground-Penetrating Radar: A Tool for Monitoring Bridge Scour. Environmental and Engineering Geoscience 13 (1): $1 \mathrm{e} 10$.

ASTM. 2007. Standard Test Method for Particle-Size Analysis of Soils. ASTM D422-63. West Conshohocken, PA: ASTM International.

2009. Standard Guide for High-Resolution Gamma-Ray Spectrometry of Soil Samples. ASTM C1402-04. West Conshohocken, PA: ASTM International.

_ 2012. Standard Test Methods for Laboratory Compaction Characteristics of Soil Using Modified Effort. ASTM D1557-12. West Conshohocken, PA: ASTM International.

Briaud, J. L., H. Chen, Y. Li, P. Nurtjahyo, and J. Wang. 2005. SRICOS-EFA Method for Contraction Scour in Fine-Grained Soils. J ournal of Geotechnical and Geoenvironmental Engineering 131 (10): 1283e94.

Clausen, J . L., T. Sobecki, A. Coplin, T. Melendy, and T. Arnold. 2016. Passive GammaRay Emission for Soil Disturbance Detection. ERDC/ CRREL TR-16-10. Hanover, NH: U.S. Army Engineer Research and Development Center. http://acwc.sdp.sirsi.net/client/search/asset/1050706.

Prendergast, L. J ., and K. Gavin. 2014. A Review of Bridge Scour Monitoring Techniques. J ournal of Rock Mechanics and Geotechnical Engineering 6:138e149.

USEPA (U.S. Environmental Protection Agency). 2016. Chapter 3: Inorganic Analytes. In Test Methods for Evaluating Solid Waste. SW-846. https://www.epa.gov/hwsw846/chapter-three-sw-846-compendium-inorganic-analytes (accessed J anuary 2016). 


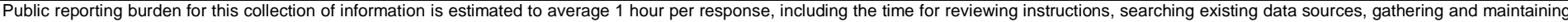

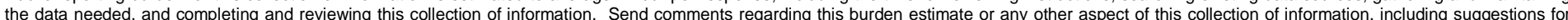

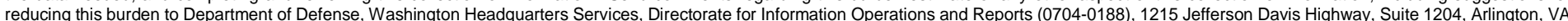

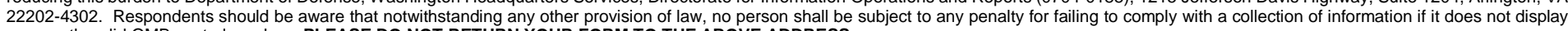
a currently valid OMB control number. PLEASE DO NOT RETURN YOUR FORM TO THE ABOVE ADDRESS.
1. REPORT DATE (DD-MM- $Y Y Y Y)$
2. REPORT TYPE
July 2017
Special Report/Final

\section{TITLE AND SUBTITLE}

Passive Gamma-Ray Emission for Underwater Sediment-Disturbance Detection

3. DATES COVERED (From - To)

5a. CONTRACT NUMBER

5b. GRANT NUMBER

5c. PROGRAM ELEMENT NUMBER

6. AUTHOR(S)

5d. PROJECT NUMBER

Jay L. Clausen

5e. TASK NUMBER

5f. WORK UNIT NUMBER

5H27CJ

7. PERFORMING ORGANIZATION NAME(S) AND ADDRESS(ES)

8. PERFORMING ORGANIZATION REPORT NUMBER

U.S. Army Engineer Research and Development Center (ERDC)

Cold Regions Research and Engineering Laboratory (CRREL)

ERDC/CRREL SR-17-3

72 Lyme Road

Hanover, NH 03755-1290

\section{SPONSORING / MONITORING AGENCY NAME(S) AND ADDRESS(ES)}

Office of the Technical Director

U.S. Army Engineer Research and Development Center (ERDC)

Cold Regions Research and Engineering Laboratory (CRREL)

72 Lyme Road

Hanover, NH 03755-1290

12. DISTRIBUTION / AVAILABILITY STATEMENT

Approved for public release; distribution is unlimited.

\section{SUPPLEMENTARY NOTES}

\section{ABSTRACT}

Sediment erosion around physical structures in surface water (e.g., bridge footings) is an important phenomenon to monitor. Traditional assessment methods rely on divers to make physical observations and measurements. Often, high currents and the high degree of turbidity of the water make these observations difficult. High turbidity can also prevent lowering a camera from a boat to make indirect visual observations.

Another possible approach to this problem is the use of gamma-ray spectrometry. This study used a handheld sodium iodide gamma-ray detector to collect in situ gamma-ray spectra of two soils submerged in water. Study results indicate that naturally occurring gamma rays being emitted by the sediment are detectable underwater. Further, the difference in gamma-ray intensity reflects density differences in the sediment due to disturbances such as erosion. A difference between the Potassium 40 (40K) activity of uncompacted and compacted soil and a comparable rate of $40 \mathrm{~K}$ signal attenuation as standing water depth increased suggests that underwater detection of in situ $40 \mathrm{~K}$ gamma-ray emissions is a potentially viable approach to assessing underwater sediment erosion.

\section{SUBJECT TERMS}

Bridges, Erosion, Footings, Gamma ray spectrometry, Potassium 40, Sedimentation and deposition, Scour (Hydraulic engineering)

\section{SECURITY CLASSIFICATION OF:}

\section{a. REPORT}

Unclassified

\section{b. ABSTRACT}

Unclassified

\section{c. THIS PAGE}

Unclassified

17. LIMITATION
OF ABSTRACT
SAR

18. NUMBER OF PAGES

19 19a. NAME OF RESPONSIBLE PERSON

19b. TELEPHONE NUMBER (include area code) 